\title{
EFFECT OF DIFFERENT VEHICLES ON HEPATO- PROTECTIVE EFFICIENCY OF DESFERRIOXAWINE IN RADIATED CARBCN TETRACHLORIDE TREATED MICE
}

\author{
Ibrahim El-Bagory ${ }^{1}$ and Mahmoud A. Mansour" ${ }^{2}$ \\ ${ }^{1}$ Department of Pharmaceutics and ${ }^{2}$ Department of Pharmacology \\ College of Pharmacy, King Saud University, P.O Box 2457, Riyadh 11451 , \\ College of Pharmacy, Saudi Arabia
}

\begin{abstract}
The effect of desferrioxamine (DFO) in different vehicle ( Aqueous and oily) against hepatotoxicity induced by carbon tetrachloride $\left(\mathrm{CCl}_{4}\right)$ in irradiated mice and irradiated carbon tetrachloride (IR-CCl$)$ in normal mice was investigated. A single dose of $\mathrm{CCl}_{4}$ and $\mathrm{IR}-\mathrm{CCl}_{4}(20 \mu / \mathrm{kg}$, i.p.) in irradiated mice (IR-mice) and normal mice induced hepatotoxicity, manifested biochemically by significant elevation of serum enzyme activities, such as alanine trarsaminase (ALT, EC:26.6.1.2) and aspartate transaminase (AST, EC:2.6.1.1). Hepatotoxicity was further evidenced by significant decrease of total sulfhydryl (-SH) content, and catalase (EC: 1.11.1.6) activity in hepatic tissues and significant increase in hepatic lipid peroxidation measured as malondialdhyde (MDA). Pretreatment of normal mice and IR-mice with DFO (200 mg/kg i.p dissolved either in water or arachis oil vehicle) $1 \mathrm{~h}$ before $\mathrm{CCl}_{4}$ or IR-CCl injection ameliorated the hepatotoxicity as evidenced by a significant reduction in the elevated levels of serum enzymes as well as a significant decrease in the hepatic MDA content and a significant increase in the total sulfhydryl content $24 \mathrm{~h}$ after $\mathrm{CCl}_{4}$ or IR-CCl 4 administration.. These results indicated that both of oily
\end{abstract}


and watery DFO can effectively ameliorated the hepatotoxicity induced by $\mathrm{CCl}_{4}$ in IR-mice or IR-CCl 4 in normal mice. Although, the efficiency of the hepatoprotective effect of DFO in oily vehicle was higher than that DFO in aqueous vehicle. The hepatoprotective effect of DFO possibly through inhibition of the production of oxygen free radicals that cause lipid peroxidation.

\section{Key Words:}

Desferrioxamine, Oil vehicle, Water vehicle, Irradiated mice, Irradiated carbon tetrachloride, Hepatotoxicity, Lipid peroxidation.

\section{Introduction}

Irradiation is a complex phenomenon in which molecules are excited, ion pairs are formed, and chain reactions are completed by free radicals [1]. Radiation offers several advantages as a sterilization method that makes it attractive in growing number of situations. Articles sterilized by radiation include a large variety of medical products $[2,3]$. The extent and nature of the damage produced in organic substances by gamma radiation was attributed to radicals produced by the irradiation [4].

Carbon tetrachloride $\left(\mathrm{CCl}_{4}\right)$ is used as solvent for oils, fats, lacquers, varnishes, rubber waxes, resins; extracting oil from flowers, seeds [5], ibuprofen in human serum [6], free chlorapheniramine in pharmaceutical preparation [7], cyclopropane for determination of cyclopropane solubility coefficients [8] and as starting material in manufacturing of many organic compounds [5].

$\mathrm{CCl}_{4}$ is a xenobiotic which produces hepatotoxicity in humans as well as in animais $[9,10]$. The hepatotoxic effect of $\mathrm{CCl}_{4}$ is thought to result from its reductive dehalogenation 
by cytochrome P-450 enzyme system to the highly reactive free radical, trichloromethyl radical $\mathrm{CCl}_{3}$ [11]. This radical quickly adds molecular oxygen to form trichloromethylperoxy radical [12]. Removal of hydrogen atoms from unsaturated fatty acids by such radical created carbon-centered lipid radicals [11]. These lipid radicals quickly add molecular oxygen to form lipid peroxyl radicals, thereby, initiating the process of lipid peroxidation. Unless scavenged by radical scavengers, these lipid peroxyl radicals in turn abstract hydrogen atoms from other lipids molecules, thereby propagating the process of lipid peroxidation [13]. Iron can catalyze oxygen free radical reactions that lead to peroxidation of membrane lipids or inactivation of antioxidant enzyme activities [14], and consequently damage of microsomes, mitochondria and nuclei that lead to imparied physiological functions of hepatocytes [15]. Also, it has been reported that iron plays a role as a mediator of $\mathrm{CCl}_{4}$-hepatotoxicity [16].

Administration of some antioxidants such as cysteamine [17], silymarin [12], tetrahydroneopeterin [18], schisandrin B [19] and vitamin E [20] has been shown to significantly suppress $\mathrm{CCl}_{4}$-induced hepatotoxicity in mice. Desferrioxamine is an iron chelator that is mainly used to treat iron poisoning [21]. The iron chelating properties of DFO has been shown to play a primary role in protecting the liver against $\mathrm{CCl}_{4}$-induced hepatotoxicity [22]. It has been demonstrated that administration of DFO prevents lipid peroxidation induced by $\mathrm{CCl}_{4}[16]$. Also, it has been reported that DFO could significantly decrease LDH leakage and reactive oxygen species production by cyanobacteria extractinduced hepatotoxicity in primary cultured rat hepatocyte [23]. Previously, we have shown that DFO attenuated hepatotoxicity induced by $\mathrm{CCl}_{4}[24]$.

Therefore, the goal of the present study was to investigate whether DFO can attenuate hepatotoxicity induced by $\mathrm{IR}-\mathrm{CCl}_{4}$ and $\mathrm{CCl}_{4}$ in normal and IR-mice respectively. 
In addition, whether using different vehicles (water or arachis oil) can affect the hepatoprotective efficiency of DFO.

\section{Experimental}

Chemicals:

Thiobarbituric acid (TBA) and arachis oil were a product of Fluka (Buchs, Switzerland). DFO (Desferal) and carbon tetrachloride were obtained from Ciba Geigy (Basel, Switzerland) and Aldrich Chemical Company (Milwaukee, WI, USA) respectively. All the remaining chemicals were of the highest analytical grade.

\section{Animats:}

Male Swiss albino mice weighing $22-25 \mathrm{~g}$ were used in all experiments. They were obtained from the Experimental Animal Care Center of King Saud University, Riyadh, KSA. Animals were maintained under standard conditions of humidity with regular light/dark cycle and free access to food (Purina Chow) and water.

\section{Gamma radiation:}

\section{A. Radiation of carbon tetrachloride}

$50 \mathrm{ml}$ of carbon tetrachloride $\left(\mathrm{CCl}_{4}\right)$ were filled into plastic tubes and were exposed to gamma radiation from Cobalt-60 source in a Gammacell 220 (Nordion International Inc. Kanata, Canada). The selected dose of the radiation in the present study was 25 kGy depending on our own preliminary experiment. The dose rate was $1.15 \mathrm{Gray} / \mathrm{second}$. The exposure time was $6.04 \mathrm{hrs}$. The zero dose (non-radiated $\mathrm{CCl}_{4}$ ) provided as a control on temperature/ storage/ transportation effects on the samples. 


\section{B. Radiation of mice}

A group of mice are subjected to the same conditions of radiation as in $\mathrm{CCl}_{4}$ procedure. The selected dose of radiation in the present study was 50 Gray. The dose rate was 1.15 Gray/ second and the exposure time was $1 \mathrm{~min}$.

\section{Experimental protocol:}

$\mathrm{CCl}_{4}(0.2 \% \mathrm{v} / \mathrm{v})$ was dissolved in corn oil and a dose of $20 \mu / \mathrm{kg}$ of $\mathrm{CCl}_{4}$ was intraperitoneally administered to mice to induce liver damage. The rise in serum ALT was taken as evidence for impaired liver function. In a preliminary experiment, $\mathrm{CCl}_{4}$ was administered to IR-mice and $I R-\mathrm{CCl}_{4}$ in normal mice at different doses ranging from 10 to $25 \mu / \mathrm{kg}$ and the dose of $20 \mu / \mathrm{kg}$ was selected in the present model, since it produces moderate hepatotoxicity. Thus the protective effects of DFO could be evaluated. In our own previous study, the peak of an increase in serum ALT activity, an index of liver injury, in mice receiving $\mathrm{CCl}_{4}$ alone, was observed at $24 \mathrm{~h}$ and started to decrease after 48 and $72 \mathrm{~h}$ [24]. A portion of DFO was dissolved in aqueous vehicle while the other was suspended in oily vehicle.

The animals were divided into 9 groups, the first group (control) received corn oil ( $10 \mathrm{~m} / 1 \mathrm{~kg}$ i.p), the second group IR-mice with 50 Gray. The third group received $\mathrm{CCl}_{4}$. $(20 \mu / \mathrm{kg}$ i.p). The fourth group was given IR- $\mathrm{CCl}_{4} .25 \mathrm{kGy}(20 \mu \mathrm{l} / \mathrm{kg}$ i.p). The fivth group was IR-mice with 50 Gray treated with $20 \mu / 1 / \mathrm{kg} \mathrm{CCl}_{4}$. The last four groups were given DFO in oily and aqueous vehicle $1 \mathrm{~h}$ before $\mathrm{CCl}_{4}$ and $\mathrm{IR}-\mathrm{CCl}_{4}$ injection in IR-mice or normal mice. In the present study, the dose of $200 \mathrm{mg} / \mathrm{kg}$ of DFO was selected, since it showed the optimum hepatoprotective effect against $\mathrm{CCl}_{4}$ as evidenced from a significant reduction of the serum enzymes tested. 
At $24 \mathrm{~h}$ after of $\mathrm{CCl}_{4}$ dosing, blood samples were drawn from the orbital plexus, under light ether anaesthesia, into non-heparinized capillary tubes. Serum was separated by centrifugation for $5 \mathrm{~min}$ at $4000 \mathrm{rm}$ and stored at $-20^{\circ} \mathrm{C}$ until analysis. The liver was isolated, washed with saline, weighed and homogenized in ice cold saline, and then $10 \%$ homogenate of the liver was made in a Branson sonifier (250, WWR Scientific, Danbury,Conn.,USA). Serum ALT and AST were determined kinetically as described earlier by Reitman and Frankul [25] using commercially available diagnostic kits (Biosystems, Barcelona, Spain). Malondialdhyde (MDA) production as an index of lipid peroxidation, total sulfhydryl content and catalase activity in the liver tissues were determined according to the methods of Ohkawa et al [26], Ellman [27] and Higgings et al [28], respectively.

Statistical analysis: Data are expressed as (means \pm SEM). Statistical comparison between different groups were done using one way analysis of variance (ANOVA) followed by Tukey-Kramer multiple comparison test. Significance was accepted at $P<0.05$.

\section{Results}

Effect of DFO on hepatotoxicity induced by $\mathrm{CCl}_{4}$ and IR-CCl in IR-mice and normal mice respectively.

Table 1 and 2 shows that i.p. injection of $\mathrm{CCl}_{4}$ and IR-CCl 4 (25 kGy) in IR-mice and normal mice induced hepatotoxicity. Serum ALT and AST were significantly increased. Pretreatment with DFO $(200 \mathrm{mg} / \mathrm{kg}$ i.p) dissolved in arachis oil vehicle prevent the significant increase in serum enzymes activities. Serum ALT and AST were significantly decreased nearly to the normal value in both groups treated (normal mice treated with IR$\mathrm{CCl}_{4}$ or IR-mice treated with $\mathrm{CCl}_{4}$ ). However, administration of DFO in aqueous vehicle 
ameliorated hepatotoxicity in both groups (IR-CCl 4 in normal mice and $\mathrm{CCl}_{4}$ in IR-mice) These were evidenced by the significant reduction in serum enzymes activities, ALT and AST. However,, it was still significant from control.

Effects of DFO (aqueous and oily) on lipid peroxide (MDA), reduced glutathione (GSH) and catalase activity in hepatic tissues.

Table 3 and 4 demonstrates that administration of IR-CCl 4 or $\mathrm{CCl}_{4}$ in normal or IR-mice induced hepatotoxicity as evidenced by significant elevation of lipid peroxide measured as MDA and significant reduction of reduced glutathione. Pretreatment with DFO (oily) significantly decreased its elevated level of lipid peroxide in both groups $\left(\mathrm{CCl}_{4}\right.$ in $\mathrm{IR}$-mice and $\mathrm{IR}-\mathrm{CCl}_{4}$ in normal mice). In addition, it prevents the significant reduction of reduced glutathione induced by $\mathrm{CCl}_{4}$. Administration of

Tab. 1. Effects of DFO on serum ALT and AST enzymes activities of mice injected with IR$\mathrm{CCl}_{4}$ DFO $(200 \mathrm{mg} / \mathrm{kg}$ i.p.) was given either in aqueous and oily vehicle $1 \mathrm{~h}$ prior to IR$\mathrm{CCl}_{4}(20 \mu \mathrm{l} / \mathrm{kg})$ injection.

\begin{tabular}{|c|c|c|}
\hline \multirow[t]{2}{*}{ 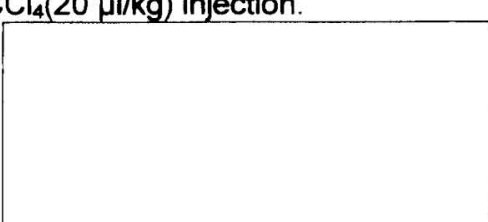 } & \multicolumn{2}{|c|}{ Serum $(M \pm S E)$} \\
\hline & $\begin{array}{l}\mathrm{ALT} \\
(\mathrm{U} / \mathrm{ml})\end{array}$ & $\begin{array}{l}\text { AST } \\
(\mathrm{U} / \mathrm{ml})\end{array}$ \\
\hline Control & $81 \pm 9.2$ & $147 \pm 17$ \\
\hline $\mathrm{CCl}_{4}+$ normal mice & $2335 \pm 467^{\star}$ & $1750384^{\star}$ \\
\hline IR-CCl + normal mice & $2392 \pm 682^{*}$ & $1900 \pm 351^{*}$ \\
\hline $\begin{array}{l}\mathrm{DFO} \text { (oily) }+\mathrm{IR}-\mathrm{CCl}_{4}+\text { normal } \\
\text { mice }\end{array}$ & $170 \pm 12^{\#}$ & $282 \pm 89^{*} \#$ \\
\hline $\begin{array}{l}\mathrm{DFO} \text { (Aq.) }+\mathrm{IR}-\mathrm{CCl}_{4} \text { +normal } \\
\text { mice }\end{array}$ & $1327 \pm 279^{*}$ & $624 \pm 185^{*} \#$ \\
\hline
\end{tabular}

* Significantly different from control group

\# Significantly different from corresponding group

\#* $P<0.05$ 
aqueous DFO attenuated the rise in lipid peroxide induced by $\mathrm{CCl}_{4}$ in both groups $\left(\mathrm{CCl}_{4}\right.$ in IR-mice and IR-CCl4 in normal mice ) and prevent the significant decrease in reduced glutathione. However, there was no significant change in catalase activity in hepatic tissues.

Tab.2. Effects of DFO on serum ALT and AST enzymes activities of IR-mice injected with $\mathrm{CCl}_{4}$. DFO $(200 \mathrm{mg} / \mathrm{kg}$ i.p. $)$ was given either in aqueous and oily vehicle1 $\mathrm{h}$ prior to $\mathrm{CCl}_{4}$ or $\mid R-\mathrm{CCl}_{4}(20 \mu \mathrm{l} / \mathrm{kg})$ injection

\begin{tabular}{|l|c|c|}
\hline \multirow{2}{*}{} & \multicolumn{2}{|c|}{ Serum (M \pm SE) } \\
\cline { 2 - 3 } & $\begin{array}{c}\text { ALT } \\
(\mathrm{U} / \mathrm{ml})\end{array}$ & $\begin{array}{c}\text { AST } \\
(\mathrm{U} / \mathrm{mI})\end{array}$ \\
\hline Control & $81 \pm 9.2$ & $147 \pm 17$ \\
\hline IR-mice & $99.4 \pm 8.2$ & $207 \pm 8.5$ \\
\hline CCl 4 and (IR-mice) & $3800 \pm 1311^{*}$ & $3062 \pm 485^{*}$ \\
\hline DFO (oily) $+\mathrm{CCl}_{4}+$ IR-mic & $220 \pm 12^{*}$ & $180 \pm 4 \#$ \\
\hline DFO (Aq.) + $\mathrm{CCl}_{4}+$ IR-mice & $994+210 \#$ & $631 \pm 17^{*} \#$ \\
\hline
\end{tabular}

* Significantly different from control group \# Significantly different from corresponding group \#* $\mathrm{P}<0.05$

\section{Discussion}

The results of the present study indicate that the DFO can protect the hepatotoxicity induced by a single administration of $\mathrm{IR}-\mathrm{CCl}_{4}(20 \mu / \mathrm{kg}$, i.p. $)$ in male Swiss albino mice and 
$\mathrm{CCl}_{4}(20 \mu / \mathrm{kg}$. i.p.) in IR-mice. Our previous study demonstrated that treatment of mice with DFO (200 mg/kg, i.p.) neither induced any change in the activities of serum ALT and AST measured nor influenced liver lipid peroxide, total sulfhydryl contents and catalase activity [24]. In the present study, pretreatment with

Tab.3. Effects of DFO on hepatic lipid peroxide and total sulfhydryl contents and catalase activity in liver homogenates of mice injected with IR-CCl 4 . DFO $(200 \mathrm{mg} / \mathrm{kg}$ i.p.) was given either in aqueous and oily vehicle $11 \mathrm{~h}$ prior to $\mid \mathrm{R}-\mathrm{CCl}_{4}(20 \mu \mathrm{l} / \mathrm{kg})$ injection.

\begin{tabular}{|c|c|c|c|}
\hline & \multicolumn{3}{|c|}{ Tissues homogenates $(\mathrm{M} \pm \mathrm{SE})$} \\
\hline & $\begin{array}{c}\text { MDA } \\
\text { (nmol/g liver) }\end{array}$ & $\begin{array}{c}\text { GSH } \\
\text { ( } \mu \mathrm{mol} / \mathrm{g} \text { liver })\end{array}$ & $\begin{array}{c}\text { Catalase } \\
\text { (mmol/min } / \mathrm{g} \\
\text { liver) }\end{array}$ \\
\hline Control & $360 \pm 30$ & $6.5 \pm 0.3$ & $123 \pm 8.5$ \\
\hline $\mathrm{CCl}_{4}$ & $1132 \pm 184^{*}$ & $2.7 \pm 0.3^{*}$ & $114 \pm 21.6$ \\
\hline $\mathrm{IR}-\mathrm{CCl}_{4}$ & $1261 \pm 149^{*}$ & $3.1 \pm 0.5^{\star}$ & $100 \pm 8.5$ \\
\hline $\mathrm{DFO}$ (oily) + IR-CCl $4+$ normal mice & $706 \pm 127^{*}$ & $5.2 \pm 0.3$ & $155 \pm 12.5$ \\
\hline $\mathrm{DFO}($ Aq. $)+\mid \mathrm{R}-\mathrm{CCl}_{4}+$ normal mice & $455 \pm 59^{\#}$ & $7.6 \pm 0.4 \#$ & $109 \pm 14.3$ \\
\hline
\end{tabular}

* Significantly different from control group \# Significantly different from Corresponding group $\#^{*} P<0.05$

DFO $\left(200 \mathrm{mg} / \mathrm{kg}\right.$, i.p.) either dissolved in aqueous or oily vehicle $1 \mathrm{~h}$ before $\mathrm{CCl}_{4}$ injection in IR-mice or $\mathrm{IR}_{-} \mathrm{CCl}_{4}(20 \mu / \mathrm{kg}$, i.p. $)$ in normal mice ameliorated hepatotoxicity. This was evidenced by a significant reduction in activities of serum enzymes, ALT and AST. Also a significant reduction in lipid peroxidation and a significant increase in total sulfhydryl 
contents were observed in the liver of $\mathrm{CCl}_{4}$-injected mice pretreated with DFO. Although an aqueous vehicle is generally

Tab.4. Effects of DFO on hepatic lipid peroxide and total sulfhydryl contents and catalase activity in liver homogenates of IR-mice injected with $\mathrm{CCl}_{4}$. DFO $(200 \mathrm{mg} / \mathrm{kg}$ i.p. $)$ was given either in aqueous and oily vehicle $1 \mathrm{~h}$ prior to $\mathrm{CCl}_{4}(20 \mu / \mathrm{kg})$ injection.

\begin{tabular}{|c|c|c|c|}
\hline & \multicolumn{3}{|c|}{ Tissues homogenates $(\mathrm{M} \pm \mathrm{SE})$} \\
\hline & $\begin{array}{c}\text { MDA } \\
\text { (nmol/g liver) }\end{array}$ & $\begin{array}{c}\text { GSH } \\
\text { ( } \mu \mathrm{mol} / \mathrm{g} \text { liver })\end{array}$ & $\begin{array}{c}\text { Catalase } \\
\text { (mmol/min/g } \\
\text { liver) }\end{array}$ \\
\hline Control & $360 \pm 30$ & $6.5 \pm 0.3$ & $123 \pm 8.5$ \\
\hline IR-mice & $320 \pm 80$ & $7.74 \pm 0.5$ & $94.8 \pm 8.7$ \\
\hline $\mathrm{CCl}_{4}$ and (IR-mice) & $1388 \pm 311^{*}$ & $4.4 \pm 0.6^{*}$ & $96 \pm 13.2$ \\
\hline $\mathrm{DFO}$ (oily) $+\mathrm{CCl}_{4}+\mathrm{IR}$-mice & $465 \pm 96^{\#}$ & $6.8 \pm 0.6 \#$ & $122 \pm 11.2$ \\
\hline $\mathrm{DFO}($ Aq. $)+\mathrm{CCl}_{4}+$ IR-mice & $472 \pm 46 \#$ & $9.5 \pm 1 \#$ & $119 \pm 11.2$ \\
\hline
\end{tabular}

* Significantly different from control group \# Significantly different from Corresponding group $\#^{\star} \mathrm{P}<0.05$

preferred for an injection, however, its use may be precluded in a formulation due to limited water solubility of a medicinal substances or a prolonged action is required [29]. Therefore, a non-aqueous solvent presently employed in parenteral products such as fixed oil, glycerine, polyethylene glycol. In the present study, i.p administration of oily DFO resulted in highly amelioration of the hepatotoxicity induced by $\mathrm{IR}-\mathrm{CCl}_{4}$ in normal mice and 
$\mathrm{CCl}_{4}$ injection in IR-mice, as the level of the serum enzymes were reduced back almost to the normal. In addition, it prevents the rise in hepatic lipid peroxide.

The biochemical mechanism involved in the development of $\mathrm{CCl}_{4}$ hepatotoxicity has been investigated. It is generally believed that this toxicity is due to lipid peroxidation caused by carbon trichloromethyl radical, $\mathrm{CCl}_{3}[30]$. In the present study, the development of liver cell injury by a single administration of $\mathrm{CCl}_{4}$ in IR-mice or IR-CCl in normal mice $(20 \mu / \mathrm{kg}$, i.p.) was associated with a significant increase in hepatic lipid peroxide content and a significant decrease in hepatic total sulfhydryl content, a potent factor in the control of lipid peroxidation [31]. These findings are consistent with a previous report [32].

The hepatoprotective effect of DFO against $\mathrm{CCl}_{4}\left(20 \mu / / \mathrm{kg}\right.$, i.p.) or IR-CCl$\left.\right|_{4}$-induced hepatotoxicity, as demonstrated by the significant reduction of increased serum ALT and AST was associated with a parallel significant inhibition of elevated hepatic lipid peroxide content and a significant increase in total sulfhydryl content in liver tissues. These findings may indicate that inhibition of lipid peroxidation is the initial event in the mechanism by which DFO ameliorates $\mathrm{CCl}_{4}$ or IR-CCl 4 -induced hepatotoxicity and is compatible with the study demonstrating that $\mathrm{CCl}_{4}$ toxicity could be ameliorated by pretreatment with inhibitors of $\mathrm{CCl}_{4}$ metabolism (33) or antioxidants [34]. This does not, however, support the work of Stacy and Klassen [35] who have reported that inhibition of lipid peroxidation can not prevent $\mathrm{CCl}_{4}$-induced cellular injury in isolated rat hepatocytes. However, In our previous study, DFO was a potent lipid peroxidation inhibitor in an in vitro study using liver homogenates of ${ }^{1}$ normal mice as a source of lipids and $\mathrm{Fe}^{3+} /$ ascorbate to induce lipid peroxidation [24]. 
In the present study DFO protected the liver of the mice against $\mathrm{CCl}_{4}$-induced hepatic damage. This finding is in harmony with the previously reported finding showed that DFO inhibits adriamycin-induced hepatotoxicity by suppression of lipid peroxidation [36]. Moreover, it has been shown that DFO could significantly decrease LDH leakage and reactive oxygen species production by cyanobacteria extract-induced hepatotoxicity in primary cultured rat hepatocytes [23]. In addition, the antidotal effects of DFO in experimental liver injury were studied by Siegers et al [22]. The authors have demonstrated that DFO can protect against hepatotoxicity induced by $\mathrm{CCl}_{4}$, but not by bromobenzene, although a marked in vivo lipid peroxidation is observed, that appears to be iron-dependent, and have indicated that lipid peroxide is not mainly responsible for bromobenzene-induced hepatotoxicity.

In conclusion: The results of the present study clearly demonstrate that both of oily and watery DFO can effectively ameliorated the hepatotoxicity induced by $\mathrm{CCl}_{4}$ in IR-mice or $\mathrm{IR}_{-} \mathrm{CCl}_{4}$ in normal mice. Although, the efficiency of the hepatoprotective effect of DFO in oily vehicle was higher than that DFO in aqueous vehicle. Further studies are needed to explore the possible mechanisms of cytoprotective actions.

\section{Acknowledgement}

The authors would like to thank engineer Nabeel Abdul Wahed, College of Science, King Saud University for providing the radiation facilities.

\section{References}

[1] Parrott, E.L., editor. Pharmaceutical Technology, Burgess Publishing Company, Minneapolis, Minn., U.S.A. 1971; 274-294

[2] Swinwood JF, Wilson BK. Treatment of cosmetics ingredients with gamma radiation: A market development view. Radiat. Phys. Chem. 1990; 35: 369-72.

[3] Dorpema JW 
Review and state of the art on radiation sterilization of medical devices

Radiat. Phys. Chem. 1990; 35: 357-360.

[4] Spinks JW and Woods RJ editors

Radiation sources, the interaction of radiation with matter

In: An introduction to radiation chemistry, $3^{\text {rd }}$ ed., John Wiley and Sons, Inc.,

New York, U.S.A. 1990; 15-45

[5] Windholz M.

The Merck Index : An Encyclopedia of Chemicals, Drugs, and Biologicals $10^{\text {th }}$

ed., Merck \& Co., Inc., N.J., U.S.A. 1983; 252-280

[6] Hoffman DJ.

Rapid GLD determination of ibuprofen in serum.

J. Pharm. Sci., 1977; $66: 749-50$

[7] Yao SZ, Zhang XT, Nie LH.

Extraction - frequencymetric method. A new measurement technique for determination of micro amounts of chloropheniramine.

J. Pharm. Sci., 1991; $80: 17-21$

[8] Halliday M M, MacDonald I, MacGregor MH.

Gas chromatographic determination of Ostwald solubility coefficient for cyclopropane. halothane and trichloroethene.

Br. J. Anaesth. 1977; 49: 413-7

[9] Stacy, N., Priestly, B.,

Dose dependent toxicity of $\mathrm{CCl}_{4}$ in isolated rat hepatocytes and the effects of hepatoprotective treatments.

Toxicol. Appl. Pharmacol. 1978; 45: 29-39.

[10] Chenery, R., George, M., Krishna, G. (1981).:

The effect of ionophore $\mathrm{A} 23187$ and calcium on $\mathrm{CCl}_{4}$-induced toxicity in cultured rat hepatocytes.

Toxicol. Appl. Pharmacol. 1981; 60: 241-252.

[11] McCay, P., Lai, E., Poyer, J., Dubose, C., and Janzen, E.

Oxygen and carbon-centered free radical formation during carbon tetrachloride metabolism: observation of lipid radical in vivo and in vitro.

J. Biol. Chem. 1984; 259: 2135-2143.

[12] Letteron, P., Labbe, G., Degott, C., Berson, A., Fromenty, B., Delafarge, M., Larrey, D., and Pessayre, D.

Mechanism for protective effects of silymarin against carbon tetrachloride induced lipid peroxidation and hepatotoxicity in mice: Evidence that silymarin acts both an inhibitor of metabolic activation and as a chain-breaking antioxidant.

Biochem. Pharmacol. 1990; 39: 2027-2034.

[13] Recknagel, $R$.

A new direction in the study of $\mathrm{CCl}_{4}$ hepatotoxicity.

Life Sci. 1983; 33: 401-408.

[14] Minotti, R. Aust, S.D.,

Studies of ascorbate-dependent, iron-catalyzing lipid peroxidation

Chem. Biol. Interact. 1989; 271: 113-119.

[15] Sipes, I.G., Krishna, G., Gillette, I.R.,

Bioactivation of carbon tetrachloride, chloroform and bromotrichloromethane: role of cytochrome P-450

Life Sci. $1977 ; 20$ : 1541-1581 
[16] Younes, M., Siegers, C.

The role of iron in the paracetamol and carbon tetrachloride induced lipid peroxidation and hepatotoxicity Chem. Biol. Intact 1985; 55: 327-334

[17] Castro, J., Cignoli, V., DeCastro, C., and Defenos, O.

Prevention by cysteamine of liver necrosis and early biochemical alterations induced by carbon tetrachloride.

Biochem. Pharmacol. 1972; 21: 49-57.

[18] Icho, T., Kojima, S., Shimhara, N., Kajiwaro, Y., Kitabatake, K., and Kubota, K., Protective effects of tetrahydroneopterin against free radical-induced liver injury. Biochem. Pharmacol. 1993; 45: 1953-1958

[19] Ip, S., Ko, K.

The crucial antioxidant actions of schisandrin-B in protecting against carbon tetrachloride hepatotoxicity in mice: A comparative study with butylated hydroxytoluene.

Biochem. Pharmacol. 1996; 52: 1687-1693.

[20] Yao, T., Esposti, D., Huang, L., Arnon, R., Spangenberger, A., Zern, M., Inhibition of carbon tetrachloride-induced liver injury by liposomes containing vitamin $\mathrm{E}$.

Am. J. Physiol., 1994; 267: G476-G484.

[21] Gilman AG., Goodman I S, Rall TW, Murad F editors

The Pharmacological Basis of Therapeutics. In Klaasen. C.D.

MacMillan, New York, Toronto, London. 1982: 16224-16245.

[22] Siegers, C.P., Steffen, B., and Younes, M.,

Antidotal effects of desferrioxamine in experimental liver injury-role of lipid peroxidation

Pharmacol. Res. Commun. 1988; 20: 337-343

[23] Ding, W. X., Shen, H.M., Zhu, H. G., Ong, C. N.

Studies on oxidative damage induced by cyanobateria extract in primary cultured rat hepatocytes

Environ. Res. 1998; 78: 12-18

[24] Mansour, M.

Protective effect of thymoquinone and desferrioxamine against carbon tetrachloride induced hepatotoxicity in normal mice.

Life Sci. 2000; 66: 2583-2591.

[25] Reitman, S., and Frankel, S.

A colomrimeteric method for the determination of serum oxalacetic and glutamic pyruvic transaminase.

Am.J. Clin. Pathol. 1955; 28: 56-63

[26] Ohkawa, H., Ohishi, N., and Yagi, K.

Assay of lipid peroxides in animal tissues by thiobarbituric acid reaction

Annal. Biochem.1979; 95: 351-358.

[27] Ellman, G.L.

Tissues sulfhydryl group

Arch. Biochem. Biophys. 1959; 82: 70-77

[28] Higgins CP, Baehner RL, McCallister J and Boxer LA. 
Polymorphnuclear leukocytes species difference in the disposal of hydrogen peroxide $\left(\mathrm{H}_{2} \mathrm{O}_{2}\right)$.

Proc. Soc. Exp. Biol. Med. 1979; 158:478-81

[29] Ansel, C.H., Allen, V. L. and Popovich, G. N. editors

In Lippincott Williams \& Wilkins. Philadelphia, 1999, 200

[30] Camps, J., Bargallo, T., and Gimenez, A.

Relationship between hepatic lipid peroxidation and fibrogenesis in carbon tetrachloride-treated rats: effects of zinc administration.

Clin. Sci. 1992; 83: 695-700.

[31] Younes, M., and Siegers, C.

Lipid peroxidation as a consequence of glutathione depletion in rat and mouse liver. Res. Commun. Chem. Pathol. Pharmacol. 1980; 27: 119-128.

[32] Nakagawa, K.

Carbon tetrachloride induced alterations in hepatic glutathione and ascorbic acid contents in mice.

Arch. Toxicol. 1993; 67: 686-690.

[33] Brady, J., Xiao, F., Wang, M., Li, Y., Ning, S., Gapac, J., and Yang, C

Effects of disulfiram on hepatic P450 IIEI other microsomal enzymes and hepatotoxicity in rats.

Toxicol. Appl. Pharmacol. 1991; 108: 366-374.

[34] Min, K., Terano, Y., Onosaka, S., and Tanaka, K.

Induction of metallothionine synthesis by nenadione or carbon tetrachloride is independent of free radical production.

Toxicol. Appl. Pharmacol. 1992; 113: 74-79.

[35] Stacy, N., and Classen, C.

Inhibition of lipid peroxidation without prevention of cellular injury in isolated rat hepatocytes.

Toxicol. Appl. Pharmacol. 1981; 58: 8-18.

[36] Al-Bekairi, A., Osman, A. M., Hafez, M. A., and Al-Harbi, M. M.,

Effect of desferrioxamine on the hepatotoxicity of adriamycin in normal mice

Drug Develop. Res. 1993; 29: 56-52. 